\title{
1. WHO CARES WHAT THEY THINK? JOHN WINSTON HOWARD, WILLIAM MORRIS HUGHES AND THE PRAGMATIC VISION OF AUSTRALIAN NATIONAL SOVEREIGNTY
}

\author{
John Fitzgerald
}

\section{Introduction}

What others think about Australia matters to Australians. Their sensitivity on this point is often playfully mocked in stories about journalists accosting visiting celebrities as they step off the plane and asking what they think about the country. But there is nothing playful about the response of Australians when they don't like what they hear. Musician Bob Dylan was asked what he thought of Australia as soon as he alighted at Sydney airport in April 1966, and was asked the same question again a week later when he flew into Melbourne. His blunt critique and trademark ironies were not well received. One miffed journalist warned Dylan that he had 'better be careful' what he said about Australia. ${ }^{1}$ 
Australian governments are equally sensitive to world opinion. In a foreign-policy address to the Sydney Institute in July 2003, Prime Minister John Howard congratulated his government for earning 'unparalleled world respect' for its stand on terrorism. This was not an ill-considered remark. Australia had played a supportive role in the Iraq war. But even before the outbreak of war in Iraq, Howard claimed on several occasions that Australia's international reputation had reached unprecedentedly high levels under his administration. ${ }^{2}$ Australia's standing in the opinion of others matters as much to national leaders today as it did to airport journalists back in 1966.

World opinion is an elusive creature. To the best of my knowledge there are no systematic surveys of Australia's current standing in the world, country by country, comparable with the Pew Global Attitudes Project which publishes half-yearly surveys of international impressions of the US and the standing of the US President. In the absence of reliable survey data, Australians have little choice but to fall back on their impressions of others' impressions of themselves. My impression is that Australia's standing in the Asian region has deteriorated rather than improved in recent years, much as the Pew Survey reveals the US image to have deteriorated in the Muslim world during the same period. ${ }^{3}$ This impression is open to correction. ${ }^{4}$ But what appears beyond dispute is the growing indifference of Australia's governing élite to the views of Asian leaders and opinion-makers in their calculation of 'world opinion'. The world opinion to which Howard refers seems to exclude the opinion of people and governments in East, South and South-East Asia, as well as 'old Europe' and possibly much of Africa and Latin America. Perhaps Australia's leaders don't like what they hear in the region, but their indifference has dangerous precedents.

Personal anecdotes and impressions offer no substitute for systematic surveys but they do help to frame questions for historical reflection. This chapter draws upon anecdotal impressions of Chinese impressions of Australia to frame questions about Australia that do not often arise when Australians reflect simply upon themselves. 


\section{Impressions of impressions}

My earliest personal encounter with a Maoist impression of Australia dates to the first industrial exhibition staged by the People's Republic of China in Australia, at the Sydney Showgrounds, in 1974. A student of Sydney University at the time, I struck up a conversation with a visiting lathe operator who stood guard over the pride of Shanghai industry of the day, huge leaden generators arrayed among stands of olive-green lathes and electric motors. 'What do you think of Australia?' I asked. He shot back immediately: 'Australia is a police state.' Things could only improve.

In Mao's day, Australia was counted a repressive police state at home and a lackey of US imperialism abroad. Such impressions were easily created and maintained through strict control of information flows that still held sway in the late Mao era. But things were changing even then. I recall standing around the TV room in a Chinese university three years later watching a television program about Sydney Harbour. For me it evoked familiar crisp mornings spent delivering newspapers around Milson's Point and Cammeray. But to my Chinese classmates, the panoramic shots of the Heads and of the harbour foreshores, of Manly ferries pulling into the Quay below towering glass buildings, close-ups of 18-foot skiffs racing across a line of Vaucluse Juniors, and footage of the bridge set against rising cumulus clouds, were altogether a profound revelation. When my classmates turned around and looked at the few Australian students on hand, the expression on their faces indicated that our local standing had risen a notch or two. Australia was a beautiful police state.

Obviously a great deal has changed in China and Australia since the 1970s. We have each followed our own routes to 'open up and reform' (gaige kaifang) our domestic societies and economies. Nobody in China considers Australia a police state any more. From reading and conversation, I can reliably report that those early impressions of Sydney Harbour are still in place. After the 2000 Olympics more people than ever are persuaded that Australia is one of the most beautiful 
and blessed countries on Earth. In the absence of reliable survey data, I would speculate that the most widespread and overriding impression of Australia is of a beautiful, clean and sparsely populated country.

Still, there are a number of stubborn continuities and disturbing discontinuities in contemporary Chinese impressions of Australia. In the past five or six years I have mixed and mingled on many occasions with Australasian experts in China's universities, academies and think-tanks. From them I have learned of two relatively new claims added to one of the old and dated ones in the past decade. First, Pauline Hanson created a widespread and abiding impression that Australians are anxious about Asia and unwelcoming to Chinese people. The view that Australians are fundamentally racist is widespread in élite circles today, spawned by news of Hansonism, reinforced by developments in refugee policy and generally understood in light of the White Australia legacy. Secondly, people are under the impression that Australia is part of Britain, or at least that our national sovereignty is somehow alienated to London. This was brought to attention by the failed referendum on the republic. Third, although they no longer consider Australia a police state, people are still largely persuaded that Australia is a lackey of the US.

These three impressions are not the result of an information black-out or false reporting. In China today, people have access to international cable television and to the World Wide Web, and with, at most, two degrees of separation can claim to know someone who has seen Australia with their own eyes. Contemporary Chinese impressions are for the most part considered judgments, based on acquired knowledge and filtered through powerful Chinese sentiments of national independence and ethnic pride.

In conversation, these three points, touching on sovereignty, independence and racism, are often folded into one question, 'When will Australia grow up?' Doubtless this question reveals as much about prevailing Chinese notions of sovereignty and independence as it does about Australia's 
alleged lack of them. A country willing to lay out hundreds of millions of dollars at short notice to keep out a few thousand illegal entrants surely takes national sovereignty very seriously indeed. But, I have been asked, why should Australia choose to make a point of national sovereignty on a matter like immigration, and decline to take a stand on the British Queen, or trail unquestioningly in the wake of US foreign policy? I am not lost for answers to this question, nor do I think Australia has much to learn from China on questions of popular sovereignty or the rule of law. But native sovereignty and independence are so highly valued in China that any attempt at an explanation for the unique Australian notion of sovereignty only illustrates the differences that divide us.

\section{Indifference}

Over the years I have tried to address these issues, one by one, in the belief that what opinion-makers and others in China happen to think about Australia matters in some material sense to the health of our bilateral relations. But something has changed in Australia's relations with China in the past six or seven years. There is a growing indifference on the part of Australia's governing élite to what people in China or Asia more generally think about Australia. A number of alarming remarks have been attributed to Prime Minister Howard himself, including one that Australia was America's 'deputy' in the region, and another that he would not hesitate to sanction a pre-emptive strike against enemies on foreign soil. His supporters claimed his comments had been read out of context. His critics said he was pandering to a domestic constituency without regard to the impact of his remarks in the region. ${ }^{5}$ Both underestimated the Prime Minister's indifference.

John Howard is neither ignorant of the impact his comments have in the region nor blind to their consequences. He appears determined to send out a clear and consistent message to people from the eastern islands of Indonesia to the western states of India. This, at least, is what my Chinese friends and colleagues tell me. The Australian Prime Minister is 
not merely pandering to a domestic constituency but sending a clear and unequivocal message in the name of Australia to a wider audience of countries in the region. The message goes something like this: we don't care what you think about us. We are who we are. Who we are is who we always have been and always will be. We don't propose to change or compromise any of our national values or beliefs simply to accommodate the views or feelings of our Asian neighbours. Australians say it like it is because sincerity is one of the things that makes us Australians. So, too, is toughness in adversity. Take it or leave it - we are not going to be messed around with. And we have big and powerful friends who will come to our aid if anyone steps out of line.

This message may be dispiriting to those Australians who are inclined to defend their country from charges of indifference to the region, or of pandering to great power politics, or indeed of implicit racism. We should rest assured that it is far less disappointing to our neighbours. It recalls a style of Australian behaviour familiar to any ageing regional president or prime minister. It is only the younger generation in China, Japan and South-East Asia that appears at all surprised. For all but the final quarter of the 20th century, Australia did its best to lock out, to patronise and, where possible, to intimidate the people and states of Asia by pointing to powerful allies who would come to our defence if they stepped out of line. The 25-year period from 1972 to 1996 was a historical aberration for our neighbours no less than for ourselves. From this perspective, Australia's effort to become better acquainted with the people, languages and cultures of Asia from the mid-1970s to the mid1990s was a masquerade that, in John Carroll's phrase, 'fools nobody'. ${ }^{6}$ We are what we are, as we always have been, and as far as the current governing élite is concerned, what we always will be. 'We' have little interest in Asia, apart from a hard-edged interest in security and trade. The rest is a matter of indifference. 


\section{Historical precedents}

Current indifference to Asian views of Australia invites historical reflection on foreign policy precedents in Australia's relations with Asia. How well did an avowedly 'pragmatic' policy of studied indifference to Asian views of Australia serve this country in the first half of the 20th century? What does its revival reveal about Australian notions of national sovereignty today?

The cult of indifference to what people in Asia think about Australia is largely unprecedented in the post-war period.The three decades of effort that went into positioning Australia as a relatively enlightened society with an independent foreign policy has not only been abandoned in the past six or seven years, but abandoned with relish. A conservative backlash against the Australian Enlightenment of the 1970s was perhaps overdue. There were mutterings all along from people currently associated with the Howard Cabinet. Less easily anticipated has been the abandonment of the liberal-conservative ideal of mutual understanding among neighbours that formed the basic post-war consensus on Australia's foreign relations in the region. The ideal of mutual understanding among neighbours has a respectable place in conservative foreign policy thinking. Prime Minister Robert Menzies, for example, commended R.G. Casey on his retirement as Minister for External Affairs for having 'done more than any other man to cultivate friendship with our Asian neighbours, and to improve that mutual understanding which is the true foundation of peace'. ${ }^{7}$ Prime Minister Howard has broken not only with the Enlightenment of the 1970s but with the Liberal tradition of the 1950s.

It could be argued that we have moved on from the 1950s, or from the 1970s, to the new world order of the 21st century. Australia's disregard for the views of Asian opinion leaders might be welcomed if it reflected a more general trend of indifference to world opinion and growing self-confidence as a sovereign and independent state. The Prime Minister's repeated comments on Australia's standing in the 'world' suggest 
otherwise. Alternatively, Australian indifference might be welcomed if it represented a step forward in Australian thinking on the limits of national sovereignty in the new world order. The evidence for this is equally slim. If anything, our cultivated indifference to regional opinion represents a return to notions of great power diplomacy and national sovereignty which have their roots in the Federation era and the Great War.

While current policy directions have little in common with the post-war consensus, they resonate with the 'pragmatic' ethos of the era of Prime Minister William Morris Hughes in the 1910s and 1920s. They get their bearings from Gallipoli and Bradman. And they target Australians who advocate closer relations with the states and societies of Asia as betraying Australia's national heritage. The heritage betrayed is a British one, dating back to the era before the Pacific War and the age of European mass migration, to a mythical time when people knew who they were and conducted their lives with the common sense, pragmatism and sobriety appropriate to their Anglo-Saxon ancestry.

In the aftermath of the Great War, Prime Minister Hughes urged Australians to deal with the world 'as it was' and not 'as we would want it to be'. ${ }^{8}$ Hughes was impatient with idealists, and especially dismissive of those who held high the Wilsonian principles of mutual respect and the sovereign equality of nations. In this he anticipated current policy directions. Pragmatic pursuit of the national interest was declared Australia's basic policy framework in the Howard Government's first foreign policy White Paper, in the mid1990s, and was reaffirmed as the guiding principle for the 21st century in the draft of the second White Paper announced in 2002. ${ }^{9}$ The latter heaped scorn on those who harboured vain hopes that Australia might strive to achieve 'international good citizenship'. Such an aspiration, in the words of the White Paper document, 'is a trap for ideologues and the naïve'. ${ }^{10}$ Hughes would have nodded his assent.

How well did Billy Hughes' pragmatism serve Australia's long-term national interests? Can pragmatism itself be 'a trap 
for ideologues and the naïve'? Shortly after his return from the post-war conference in Paris, Hughes gave an account of his diplomatic success there. He likened his own achievements in Paris to those of the Anzacs who had preceded him to Europe. 'White Australia is yours,' he announced to the assembled parliamentarians. '[Our] soldiers have achieved the victory, and my colleagues and I have brought that great principle [of White Australia] back to you from the conference, as safe as it was on the day when it was first adopted. ${ }^{11} \mathrm{He}$ also spelled out what these victories meant for the exercise of Australian national sovereignty. Australians alone would decide who came into this country, he told the House of Representatives in September 1919, and the people themselves had decided 'that none should enter in, except such as they chose'. ${ }^{12}$

The Great War was fought for King and Country, of course, not merely to decide 'who should enter in', as Hughes put it. At the federal level, however, the war was rapidly turned to the service of immigration restriction under the rubric of 'White Australia'. This was consistent with the federal level of government after Federation. Among settler colonies of the Pacific Rim, only in Australia did national immigration policy come to bear a sentimental association with national sovereignty. White Australia hinted at something more than the sum of the legislative parts of the Immigration Restriction Act. It elevated the mundane practices of customs officials to the level of a sacred duty.

Racial exclusion, John Hirst points out, was not a significant factor in the decisions and processes leading to Federation 20 years earlier. ${ }^{13}$ The sequence actually worked the other way. Federation turned out to be such an insipid affair that it invited more inspiring visions to embolden or supplant it at the national level. Donald Horne has suggested that it was the pragmatism of Federation that accounted for the heavy emphasis placed on White Australia as an ideology in the years after Federation. Pragmatism and racism went together. The 'emptiness of "purpose" in the Constitution', Horne suggested, may have given sharp, extra meaning to the idea of 'Australia 
for the White Man'. In Canada there was a 'White Canada' movement and there was agitation against coloured immigrants in the US. But in neither country was race chauvinism used as the exclusive means of defining the nation, alone giving it public identity and purpose. In Australia it was given this function. This unique emphasis may have been provided by the accident that in 1901 a federation had occurred without proper rhetorical warning: Federation was given retrospective meaning by the Commonwealth's implementation of the White Australia Policy.

Racial exclusion became important after Federation once elected parliamentarians mounted a higher federal stage from which they could pronounce on elevated matters of national purpose beyond the narrow purview of colonial or state perspectives. 'They needed a great self-defining debate: that ritual debate happened to be on immigration policy,' Donald Horne remarked. ${ }^{14}$

As far as national visions went, Federation and the Great War converged at two points not often to be found at the birth of sovereign nations. First, neither had much to say about national independence. Federation was an act of local administrative unification, effectively centralising the states' colonial ties with Britain through the new Commonwealth Government, while Gallipoli showed the price Australians were prepared to pay in blood to maintain their ties with the Empire. Second, both events helped to craft a distinctive form of sovereignty that focused sentimental regard on territorial borders and border control. At Federation, the founding fathers drafted a national covenant that defined national sovereignty as the right to determine who and what does and does not come into the country. Protectionism and, in time, White Australia gave explicit content to this covenant.

In the aftermath of the Great War, Prime Minster Hughes sealed this covenant with the rhetoric of wartime sacrifice and valour. ${ }^{15}$ The basic covenant is so deeply embedded in the rituals and rhetoric of Australian public life that it readily survives the abolition of its specific content 
(White Australia or trade protection) and continues to incite passionate feelings about Australian sovereignty. To this day, the exercise of national sovereignty in Australia is chiefly associated with the relatively trivial right of determining who, and what, comes into the country. Native sovereignty and national independence count for little alongside an obsession with border control. ${ }^{16}$

This limited notion of sovereignty seems to be an accidental consequence of the global timing of Federation. Late in the 19th century, national borders were hardening around the world after a period of massive population flows and capital transfers from continent to continent in the preceding century. The period that is remembered in Australia as the Federation era is remembered elsewhere as the concluding phase of the Atlantic Century - a century in which capital and merchandise moved as freely as people under relatively relaxed trade and customs controls. This passage in the development of the global economy cooled off from about the turn of the century, with the introduction of passports and immigration controls and, more drastically, with the imposition of trade barriers. ${ }^{17}$ The subsequent period of global contraction yielded an ideal of an autarkic national state that could exercise absolute control over its economic, demographic and cultural boundaries.

This was the moment at which the Australian colonies chose to federate - the new Commonwealth of Australia came into being when border control and racial exclusion were in the air. Australia's Federation was profoundly shaped by this historical experience. The deepest fissures to emerge in debates leading up to Federation in 1901 opened up around disputes between free traders and protectionists, and to a modest degree between champions of greater or lesser restrictions on Asian immigration. In either case, debate turned on the issue of who and what should be let in. The question framed and continues to frame Australian conceptions of sovereignty.

Here a distinction is in order. There was nothing uniquely Australian about preoccupations with border control at the close of the 19th century. National legislation aimed at 
excluding Chinese immigrants was common among settler states on the Pacific Rim, and Australia was neither the first nor the only country to adopt racial immigration restrictions as national policy. In 1882, the US Congress passed the Chinese Exclusion Act to deny Chinese entry into American ports and to deny resident Chinese the right to naturalisation. The US Chinese Exclusion Act was not repealed until 1943. ${ }^{18}$ Canada enforced national restrictions for four decades from 1885 through the imposition of a federal poll tax on Chinese applicants for entry. The poll tax had the effect of limiting the Chinese population of Canada to about 40,000 by the early 1920s - a figure of the same order, relative to population, as the Australian Chinese population during the 'White Australia' era. From the 1920s it was even more restrictive. ${ }^{19}$

What was uniquely Australian was the visionary or patriotic dimension of immigration controls, a feature largely missing from the North American experience. Canada did not become Canada or the North American colonies the USA on the back of arguments about preserving racial purity through a discriminatory immigration regime. Australia did. For the same reason, Canada could abandon the slogan 'White Canada' more readily than Australia can caste aside the baggage of 'White Australia'. Although Australia has practised nondiscriminatory immigration procedures since the early 1970s, the right to say who can and cannot come into the country remains the core assumption underlying the exercise of national sovereignty. Immigration controls made us what we were, what we are and, in a sense, what we always will be.

\section{Pragmatism, principle and implications for sovereignty}

When the war was over, Hughes travelled to Europe to ensure that this ennobled vision of White Australia was understood and appreciated by the delegates who assembled in Paris to determine the fate of the world in the post-war era. There he fought and won a battle to prevent the international adoption of a Racial Equality clause in the preamble to the Charter of the League of Nations. Prime Minister Hughes seized upon the 
sacrifices of Gallipoli to promote a federal obsession with border control beyond Australia to the world at large. He sacrificed the principle of racial equality on the altar of pragmatism.

Hughes was a wily and stubborn politician. He spoke the local dialect of Australian nationalism, and proclaimed it loudly and brazenly to the world, in the conviction that this was what good and honest Australian patriots should do. Australian Britons were all the better distinguished from British ones by their impatient disregard for the niceties of élite diplomacy and their blunt reactions to the effete conceits of international conferences and treaties. ${ }^{20}$ Hughes' blunt diplomacy was certainly popular at home. He had a special gift for reading the mood of the electorate and for finding words and images to turn fleeting popular sentiment to his own political advantage. At the same time, he saw himself as an honest, sincere and practical man of action, whose duty it was to represent the Australian national interest as honestly as he could, whatever others may have thought of him or his country on this account. While proclaiming himself a pragmatist, working tirelessly for the national interest, Hughes assumed that the national interest meant preserving the British Empire and keeping Australia white. His pragmatism was driven by ideals to an extent that he rarely acknowledged himself.

His 'romantic pragmatism' made Hughes a formidable political opponent. ${ }^{21}$ Hughes' local rivals in Sydney, Melbourne, Brisbane and, in time, Canberra learned to respect the political acumen of the 'Little Digger'. So did the British, Americans and Japanese with whom he argued and negotiated over key clauses of the Peace Agreement in Paris after the war. In time, a good number of people and nations learned to live with defeat at the hands of the romantic Australian pragmatist.

For Hughes every question of principle needed to be reduced to a more basic question of what practical benefit it would confer on Australia before it merited serious attention. He had no patience, for example, with the principle of racial equality supported by US President Woodrow Wilson after the war. To concede the principle of racial equality at an 
international forum would, he believed, have placed Australian sovereignty at risk. Hughes set out openly and deliberately to undermine international efforts to uphold racial equality as a universal principle in the post-war international order so as to preserve the most important ingredient in Australian sovereignty - the right to say who could come in.

Immediately after the war, Hughes went to Paris to discuss the terms of peace and take part in negotiations leading to the creation of the League of Nations. He took a stand on three main issues: German reparations, Australian mandates over former German territories in the Pacific and racial equality. Ever the practical man, Hughes had a bottom line on each issue. He sought massive punitive damages against Germany, bartered for as many colonial possessions as possible for Australia in the Pacific, and, of special note, fought for the deletion of any reference to racial equality in the formal documents issuing from the conference. The terms of peace, Hughes announced shortly before the Peace Conference began, 'must deal with the world and human nature as they are, and not as they would have them be'. ${ }^{22}$ He heaped scorn on those who imagined that a just international settlement might achieve a peaceful outcome. For Hughes, open discussion of the dangers of racial equality marked the only practical way forward.

In the spring of 1919, Hughes became embroiled in a crisis involving the Japanese, British and US delegations in Paris, centring on his unwavering commitment to keeping Australia white. Leading members of the Japanese delegation put forward a proposal to insert a racial equality clause into the preamble of the Covenant to the League of Nations. ${ }^{23}$ President Wilson was sympathetic, Lloyd George prevaricated, but Billy Hughes was forthright in his opposition. Any statement asserting the principle of the equality of races would have placed in jeopardy the vision of White Australia for which, by Hughes' account, Australia's young men had fought and died in Europe. To undermine President Wilson's principled support for the racial equality clause, Hughes threatened to stir up anti-Wilson sentiment in local constituencies in the US, where race was 
a sensitive issue in pending elections. ${ }^{24}$ His political apprenticeship in Australia had tutored him sufficiently in populist politics to intimidate a US President. In February and March 1919, the Japanese delegation met with members of the British and American delegations to secure their support for the racial equality clause. While others vacillated, Hughes would not budge. As the Japanese delegation reported to the Japanese Foreign Ministry after one meeting with Hughes, 'The fate of our proposal lies in the hands of one man, the Australian Prime Minister. ${ }^{25}$

In the end, Australian pragmatism won out. Hughes garnered sufficient support at the conference to reduce the vote in favour of inserting a racial equality clause into the preamble to a simple majority. This was enough to scuttle it. For Hughes, the defeat of the racial equality clause was a triumphal demonstration of Australian national sovereignty - specifically, the national right to determine who could and could not come into the country. For Japan, it was a humiliation not forgotten to this day.

Hughes, it should be noted, had no problem acknowledging the equality of races 'out there' in the world. But he would not admit the equality of races 'in here' within the Australian nation itself. Hughes chiefly objected to the racial equality clause on the grounds that the Australian Federal Government alone would say who could and could not come into the country, and he reserved the right to employ race as a category for exclusion. Hughes believed this was a local issue of no particular relevance to others. What others thought was of little consequence. Issues of immigration and race were 'purely domestic matters', he told the Japanese delegation at Versailles. Immigration was none of their business. ${ }^{26}$

\section{Pragmatism and its consequences}

In fact, significant international repercussions did flow from the defeat of the racial equality clause in 1919. When Hughes took to badgering British Prime Minister Lloyd George over the clause, the South African representative, General J.C. Smuts, was asked to intervene. Smuts advised the Japanese delegation 
that Hughes spoke with an independent voice and not on behalf of Britain. He added, for good effect, that Hughes 'was by nature very narrow-minded and was not the kind of man to consider international implications. ${ }^{27}$ Hughes failed to acknowledge the degree to which international diplomacy was shaped by 'domestic matters' or to concede that his single-minded pursuit of Australian domestic issues at the Paris convention could shape international relations for decades to come.

What was the practical outcome of Hughes' 'pragmatic' foreign policy? On these questions our Asian-language sources are variously shrill and silent. They are loud and emphatic in Japan but still largely silent in China. First, his behaviour alienated the Japanese Government at a time when Australia could ill afford to give offence. Major E.L. Piesse, Australia's Director of Military Intelligence, noted at the time that Hughes' attitude caused grave offence in Japan and that memories of this humiliation could have long-term consequences for Australia. Hughes, wrote Piesse, 'has chosen to emphasise the national distinctions between the Japanese and ourselves in a way that could not fail to be offensive to a high spirited people ... their effect in Japan has been most serious'. ${ }^{28}$ Hughes may have been indifferent but the offence was neither forgiven nor forgotten. Today, Hughes is far less well remembered in Australia than he is in Japan, where his exploits in Paris continue to be retold, again and again, in popular and textbook histories of Japanese nationalism and Australian racism. The 'Little Digger' is considered to be the quintessential Australian: rude, ignorant of world affairs, narrow-minded and deaf to the demands of international good citizenship. ${ }^{29}$

The second international repercussion was an indirect one, though no less important for the post-war international order than the humiliation of Japan. The American delegates came up with a face-saving gesture to compensate the Japanese delegation for the defeat of the racial equality clause. Sean Brawley mounts a persuasive case that the Americans made a secret concession to the Japanese delegation in the closing days of the convention. To mollify the aggrieved Japanese, they 
acceded to Japan's request to take control of German possessions in China which Japanese forces had confiscated from Germany during the war. By trading Chinese territory for the principle of racial equality, Brawley writes, "Wilson had to give Japan "what they should not have" because he could not give them what they should have' - an international commitment to the principled equality of races. ${ }^{30}$ By his actions, Hughes had ensured that Wilson could not deliver on racial equality.

For China's domestic politics, this secret agreement was one of the most far-reaching decisions ever taken in an international forum. Now it was the turn of the Chinese people to feel humiliated. China's delegation in Paris, representing the new Republican Government, protested, but to no avail. In Beijing the Prime Minister fell, and with him the hopes of the liberal parliamentary movement, which fell in turn to Leninist parties in the wake of the fateful decision at Versailles. Hughes' 'pragmatic' interest in scuttling the racial equality clause at the Paris conference led to the downfall of the new Chinese liberal republic.

It did more. On hearing the news from Paris, students took to the streets of Beijing in May 1919, founding a movement that is still remembered in Chinese communist historiography as the inaugural or founding moment of the communist revolution: the May Fourth Movement. While protesting the surrender of Chinese territories to Japan, students brandished signs calling for the removal of the democratic government of China and an end to all foreign imperialism. Leading public figures in Shanghai, Canton and Beijing emerged to denounce the republican government for failing to defend the country's national sovereignty. Russian agents and representatives of the Communist International moved in among students, teachers, workers and Chinese political reformers, setting up networks of radical cells that would introduce a new and more powerful form of government that would rid China of Japanese, British, American and other foreign imperialists for ever. Within a few years, Sun Yatsen abandoned his commitment to liberal 
democracy, signed up with the Russians, reorganised his Chinese Nationalist Party into a Leninist party, and set up a single-party state in Canton - the precursor to the Communist Party one. In 1921, the Comintern's small political cells converged to form the Chinese Communist Party. As a party of the working class, the communist movement was of little consequence. Once it learned to harness mass discontent with foreign humiliation and colonial infringements of China's territory, the communist movement grew to become the most powerful political organisation in the country.

We would be drawing a long bow to attribute the birth of communist China to the words and actions of Hughes at Versailles. Still, we can place the actions of Prime Minister Hughes at the peace conference into a clear causal sequence stretching from Paris to Tokyo, and across the Sea of Japan to Beijing, even if these international outcomes were only partly of Hughes' making. By sticking to his narrowly 'pragmatic' defence of Australian sovereignty — conceived as border control - and publicly professing racism on the world stage, Hughes gave succour to China's communists. Australia was one of several sites of anti-Chinese racism on the Pacific Rim. But only the Australian Government adopted a principled and patriotic position on the subject. Publicly enunciated as White Australia, Australia's unique brand of patriotic racism was a source of constant humiliation to people in China and to people of Chinese descent in South-East Asia, in the Americas and in Australia itself. So it remains to this day. Humiliation is a powerful instrument of nationalist politics. The communists used it well to secure victory in 1949 and to win international acceptance among Chinese communities the world over for decades to come.

\section{Conclusion}

Chinese impressions of Australian public life today invite us to reflect on the relationship between our hard-headed pragmatism and our limited ideal of national sovereignty. We could, of course, reject these impressions out of hand as biased or ill- 
informed. The alternative is to take them seriously if only for pragmatic reasons. They give us occasion to reflect historically on the link between our avowed pragmatism and the implicit idealism that underpins it, grounded in Australia's case in a particular historical vision of national sovereignty. In Australia, a recurring obsession with border control overshadows aspects of national sovereignty which other states take seriously. To turn this observation around, Australia's institutional indifference to native sovereignty and to national independence leaves patriotic sentiment nowhere to go but out on patrol.

When pragmatism is elevated to a principle it, too, can become 'a trap for ideologues and the naïve', no less than unreflective idealism. ${ }^{31}$ There is little to be said for idealistic future-watching divorced from achievable outcomes. That said, it is not only idealists who fashion futures. When Hughes dealt with the world 'as it was' he helped make the world what it would yet become. He was rightly wary of Japan's potential for overseas expansion and China's capacity to 'wake up and shake the world', but his romantic pragmatism did little to deter them. In the 1920s, Australia's leading role in undermining the principle of racial equality and its practice of racial exclusion in the name of national sovereignty significantly diminished the prospects for a just international settlement in the post-war era. Naïve pragmatism was, in the end, a cause of war and revolution, not a means of avoiding them. Australian pragmatism yielded the very spectre which pragmatists most deeply feared: the emergence of powerful and heavily armed states in East Asia.

Today, contemporary Australian foreign policy seems paradoxical to observers in China. While Australia closely follows the US lead, in pursuit of avowedly pragmatic goals, it is actually helping to remake the world according to an American vision of how the world 'should be'. In November 2002, the Bush administration rejected out of hand European pleas for Washington to deal with the world 'as it is' in dealing with Iraq. The Washington Post's Jim Hoagland rose to defend the Bush administration. The Europeans' appeal to deal with the world 
'as it is', he pointed out, 'ignores how rapidly and dramatically the world is changing ... Equivocation and tinkering - the heart and soul of Europe's current diplomacy — is rapidly falling behind history's ever accelerating curve'. ${ }^{32}$ In fact, Washington seeks to 'straighten out the untidy world in which we live', another observer argues, without reference to alliances, multilateral frameworks, rules or even treaties. ${ }^{33}$ On the one side is a vision of a rules-based international system, founded on the dignity and equality of sovereign nations and, on the other, a vision of the US as a world system in which national sovereignty plays little part. A country such as Australia, which places little value on native sovereignty and national independence, may not appreciate the difference between a rules-based and a Washington-based system. Other countries in the region do appreciate the difference, and they evaluate us on the same account.

To the outside observer, Australia's foreign policy does not appear to lack vision or ideology; it merely lacks Australian vision or ideology. This paradox is at once a measure of our dependence and the stamp of our autonomy. Our dependence on the US provides an autonomous space within which Australia can be merely 'pragmatic', a luxury Washington has long since discarded and which President George W. Bush can ill afford.

We might well reflect on the lasting significance of a characteristic Australian notion of national sovereignty that would focus on the sovereign right to determine who does and does not come into the country to the exclusion of native sovereignty or international independence. No matter how we may try to deny or to escape the racist implications of this form of sovereignty - for example, by pointing to the nondiscriminatory nature of our current immigration and refugee policies - we cannot avoid returning to the source of the distinctive conception of sovereignty itself. The right to say who can come in to this country is the foundational assumption of the Australian nation. It made us who we were, who we are and who we always will be. That said, we cannot escape the 
origins of this skewed conception of sovereignty in the White Australia Policy. We can certainly evacuate our conception of sovereignty of its racist content but we can no more deny its origins in racism than American historians can deny that Thomas Jefferson kept slaves.

Australian racism will continue to surface in Australia's relations with the region, in Australian nationalism and as a dominant theme in Australian history, not because nationalists are all 'racist' nor because historians all don black arm-bands. It will surface for the same reason that slavery surfaces in celebrations of American patriotism or in reflections on US history. The more Americans dwell on their sovereign right to be counted free and equal, the more they discover the inequality and bondage that has at times characterised their nation. The more Australians stress our sovereign right to patrol our borders - by advertising that we alone determine who comes into this country - the more we focus the region's attention on why we feel so keenly about it. However assiduously we may cultivate indifference to the views of our neighbours, this is one impression of theirs that is unlikely to fade away. 


\section{Footnotes}

$1 \quad$ Sydney Airport, 12 April, 1966: Reporter: 'What are your impressions of Australia?' Dylan: 'Australia isn't a very nice place for lots of people - people like Orientals and Negroes.' Reporter: 'Perhaps you'd better be careful what you say.' Melbourne Airport, 17 April, 1966: Reporter: 'What do you think about Australia?' Dylan: 'Since I was a little boy I have heard about Australia. I once knew someone who knew somebody who knew somebody whose grandfather was supposed to have been to Australia. This gave me a tremendous curiosity to find out whether this fellow really did have a grandfather.' From Hamilton, Paul and Karen Morden. The Freespieling Bob Dylan. www.idler.co.uk/html/frontsection/dylan.htm PM signals more action for troops. The Age, 2 July, 2003. Mr Howard made a similar claim in April 2002. See Transcript of the Prime Minister the Hon John Howard MP. The Prime Minister's Closing Address, Liberal Party 49th Federal Council, Hyatt Hotel, Canberra. 14 April, 2002. http://www.pm.gov.au/news/speeches/ 2002/speech 1596.htm. I wish to thank Meg Gurry for the 2002 reference.

3 See the Pew Research Center web site at www.people-press.org John Carroll, for example, argues that the countries of Asia envy our close alliance with the US, applaud our pragmatic foreign policy and respect the values and institutions which distinguish Australia from other countries in the region. 'It is John Howard,' Carroll writes, 'not Paul Keating, who has got these relationships right.' See Carroll, John. 2003. Howard navigating a safe diplomatic course. Australian Financial Review, 9 January, 2003.

Michelle Grattan observes that John Howard's comments and responses seem to have been made with an eye to his 'domestic constituency'. The Age, 4 December, 2002.

Carroll, John. 2003. Howard navigating a safe diplomatic course. Australian Financial Review, 9 January, 2003.

The Age, 25 January, 1960. Cited in Millar, T.B. (ed.). 1972. Australian Foreign Minister: The Diaries of R.G. Casey 1951-1960. p.12. London: Collins. I wish to thank Antonia Finnane for this reference.

Cited in Meaney, Neville. 1976. The Search for Security in the Pacific, 1901-1914. p.45. Sydney: Sydney University Press.

The White Paper that framed foreign and trade policy in the first two terms of the Howard Government was titled In The National Interest (August 1997). 
Foreign Minister Alexander Downer. Advancing the National Interest: Australia's Foreign Policy Challenge. National Press Club, Canberra. 7 May, 2002.

Hughes to Parliament. Reported in Deane, P.E. Australia's Rights: The Fight at the Peace Table. See ABC web site.

Cited in Hudson, W.J. 1978. Billy Hughes in Paris: The Birth of Australian Diplomacy. p.66. Melbourne: Thomas Nelson.

Hirst, John. Chinese Immigration and Australian Sentiment at Federation. In Couchman, Sophie, John Fitzgerald and Paul Macgregor (eds), forthcoming, After the Rush: Regulation, Participation and Australia's Chinese Communities, 1860-1940.

Horne, Donald. 2000. Billy Hughes: Prime Minister of Australia 19151923. pp.75-6. Melbourne: Black Ink.

'White Australia,' Hughes confided in a memo at the Paris Peace Conference,' is the cornerstone of the national edifice.' Fitzhardinge, L.F. 1979. The Little Digger: William Morris Hughes, A Political Biography, Volume II, 1914-1952. p.398. Sydney: Angus \& Robertson. His Private Secretary, Percy Deane, later recalled of Hughes' work at the Paris conference that 'the Prime Minister was called upon to battle desperately for this [White Australia], compared to which our sacrifices in war, our achievements, our gains, fade into insignificance. For we would gladly sacrifice as much again - or give up all that we have gained - rather than forsake this policy.' Deane, P.E. 1920. Australia's Rights: The Fight at the Peace Table. Political Pamphlet. This reference can be found on the ABC Federation web site http://www.abc.net.au/federation/fedstory/ ep2/ep2_places.htm. C.E.W. Bean, the historian who gave shape to the Anzac legend, was persuaded that Australians had fought and died at Gallipoli for the one social ideal they knew, 'that of race'. See Meaney, Neville. 1999. Towards a New Vision: Australia and Japan - Through A Hundred Years. p.25. East Roseville, NSW: Kangaroo Press.

See, for example, the exhibition mounted by Australian Customs to commemorate the Centenary of Federation, which equates people with fruit and worm-eaten wood. The opening exhibits feature confiscated ivory, woodwork and narcotics. Later exhibits culminate in a display of sandals and Thermos flasks from the hopeful Chinese refugees who stepped on to Australian beaches in the 1990s.

O'Rourke, Kevin and Jeffrey Williamson. 1999. Globalisation and History: The Evolution of a Nineteenth Century Atlantic Economy. Boston, Mass.: MIT Press. 
Even after repeal of the Act in 1943, the level of immigration from China was formally restricted to about 100 people a year until Congress passed the non-discriminatory Immigration Act of 1965. Gyory, Andrew. 1998. Closing the Gate: Race, Politics, and the Chinese Exclusion Act. Chapel Hill, NC: University of North Carolina Press. Pan, Lynn (ed.). 1999. The Encyclopedia of the Chinese Overseas. pp.261-73. Cambridge, Mass.: Harvard University Press.

From 1923, the Canadian Government enforced an even stricter regime. The 1923 Exclusion Act was so rigorously enforced that it is reported to have limited the entry of Chinese settlers into Canada to a total of about two dozen people up to the end of World War II at a rate of about one person a year. Far more Chinese entered Australia in the same period. The Canadian restrictions were eased in 1947 to allow entry of close family relatives of Canadian Chinese citizens. Still, independent Chinese immigrants were not granted entry until 1962. Chinese Canadians were also subject to discriminatory legislation that was in some respects similar to Australian legislation and in others more severe. In British Columbia, for example, Chinese Canadians were disenfranchised in provincial and federal elections from 1875 to 1947. Pan, Lynn (ed.). 1999. The Encyclopedia of the Chinese Overseas. pp.234-47. Cambridge, Mass.: Harvard University Press. See Horne, Billy Hughes, pp.109-13 and passim.

Donald Horne applies the term 'romantic pragmatist' to Hughes. Ibid. Two drafts were proposed, one of which was further modified before the clause was put to a vote. The first draft, preferred by the Japanese delegation, read: 'The equality of nations being a basic principle of the League, the High Contracting Parties agree that concerning the treatment and rights to be accorded to aliens in their territories they will not discriminate, either in law or in fact, against any person or persons on account of his or their race or nationality.' The alternative version read: 'The equality of nations being a basic principle of the League of Nations, the High Contracting Parties agree that concerning the treatment of aliens in their territories, they will accord them, as far as it lies in their legitimate powers, equal treatment and rights, in law and in fact, without making any distinction on account of their race or nationality.' Ibid., p.401. 
Brown, Frank C. n.d. They Called Him Billy. p.155. Sydney: Peter Huston. Brown notes approvingly, 'The fact that the United States President was a politician with a politician's weaknesses, had been overlooked by almost everybody at the Peace Conference. But not by Billy.'

Cited in Fitzhardinge, The Little Digger Vol. II. p.405.

26 Ibid., p.407-10.

27 Ibid., p.404.

28 Major Piesse, March 24, 1919, Naval Office, Melbourne. MP, NAA 1049/1, 1918/049. See ABC web site.

29 That Hughes was seen in Japan as the 'typical Australian' was made clear to Australian delegates to the Institute of Pacific Relations as early as the 1920s. See Brawley, Sean. 1997. The White Peril: Foreign Relations and Asian Immigration to Australasia and North America, 1919-1978. p.97. Kensington: University of NSW Press.

30 Brawley, The White Peril, Chapter 4, passim, esp. p.33. See also Hudson, Billy Hughes in Paris, p.58.

31 Foreign Minister Alexander Downer. Advancing the National Interest: Australia's Foreign Policy Challenge. National Press Club, Canberra. 7 May, 2002. International Herald Tribune, 18 November, 2002.

33 Lewis, Anthony. 2002. Bush and Iraq. pp.4-6. New York Review of Books, 7 November, 2002. 